\title{
The Relationship Between the Level of Satisfaction on The Growth of Instagramable Place and Motivation of the Users in Increasing Income
}

\author{
Cynthia Setiawan', Lamtiur Hasianna Tampubolon ${ }^{2, *}$ \\ ${ }^{1}$ The School of Business Administration, Atma Jaya Catholic University, Indonesia \\ ${ }^{2}$ Department of Magister of Business Administration, Atma Jaya Catholic University, Indonesia \\ *Email: lamtiur.tamp@atmajaya.ac.id
}

\begin{abstract}
Instagram in Indonesia is used as a Marketing Strategy. Along with the development of the use of Instagram, gave rise to the trend of new lifestyles and habits that have an impact on the improvement of the appearance of Instagramable places. One of the most Instagramable which became the goal of the millennial generation is the island of Bali. The island is a tourist destination that is a complete, integrated and has many tourist attractions Instagramable. The purpose of this research is to study the relationship between the level of satisfaction on the growth of Instagramable places and motivation of the users in increasing income. The type of research used in this study is a research associate with the use of quantitative methods and data collection techniques with the dissemination of the questionnaire to the 130 respondents. The research concludes there is a positive relationship with the level of medium strength between the satisfaction on the growth of instagramable place and the motivation of users in increasing their income with a score of 0.486 using the calculation of the correlation test manually.
\end{abstract}

Keywords: Instagram; digital business; consumer satisfaction; consumer motivations

\section{Introduction}

Information technology being an integral part of today's society. The development of technology and information in such a rapid has entered all areas of human life so it can't be denied that the need for technology and information is very high. Basically, information technology is a technology that is used to process data, included in the process, obtain, collate, store and manipulate data in different ways to create or generate highly quality information. In other words, information technology is a technology to produce a relevant information, strategic and accurate.

For example, the internet, nowadays the development of technology and information such as the internet is something very important to most people. Because with the internet we can access and find all the information quickly and easily, therefore the use of the internet always increases each year. In Indonesia, the number of internet users increases with a great number.

The market research Institute e-Marketer putting together an internet usage data in 2013-2018. From these data it can be seen that the internet users in Indonesia in the year 2013 were 72.8 million. While in the year 2018, internet users in Indonesia reached 123 million people so it can be said that internet users have increased each year. These data in 2013-2018 also shows that in the year 2018, Indonesia as a developing country has the largest population of internet users surpass the developed countries like Japan with internet users as much as 105.4 million people (Kementerian Komunikasi dan Informatika Republik Indonesia, 2014).

Social media is more widely used nowadays is Instagram. Instagram became an application to share experiences and express yourself with the different ways, either through pictures, video or caption used as explanatory captions images or videos that are uploaded. Instagram is one of the media that is experiencing tremendous growth along with behavior change world society that is becoming increasingly "tied" to information technology. Based on statistical data, at the beginning of the year 2013 is recorded as many as 90 million active users have joined social media using Instagram. That number continued to experience considerable increase in every year so that by the year 2018 it reached 1 billion users (Clement, 2018). 
Nowadays, Instagram is not only a media for uploading photo or video, but it becomes the most influential social media for selling a business product; it becomes a marketing strategy or a media for business actors to promote a product or a service. Instagram is becoming the platform of choice for the actors of Micro small and medium enterprises (UMKM) to market their products and services. It can be seen from the results of research carried out, most of the SMEC Indonesia agree makes Instagram as an option, with the details: $87 \%$ Indonesia SMEC surveyed agree that their sales are rising because of Instagram, 66\% strongly agree that Instagram helping them to find new customers more than other platforms, and $63 \%$ of them was able to establish closer relations and meaningful customers (Kurniawan, 2018).

Not only for the UMKM, companies especially those in the field of services also utilize media Instagram to help their business development and finding new customers. One of the companies that utilize media Instagram as one of its business platforms is the "Garuda Organizer".

PT Garuda Nusantara Kencana (Garuda Organizer) is a company engaged in the field event specialist. Garuda Organizer established in August 2012 and is the successor of the previous event specialist company, namely the "Prestige Organizer". As for a regular event organized by the "Garuda Organizer" each year among other is Career Expo, Campus Hiring, Career Fair, Campus Network to Simply Pop Up Market. Simply Pop Up Market is a bazaar events often organized by the company "Garuda Organizer" each month. To conduct Simply Pop Up Market, "Garuda Organizer" uses the Instagram as marketing strategy to find tenants who were willing to participate in the Bazaar as one way to promote its event.

In addition, related to the abundance of interest of Instagram, users have spawned various Instagramable places in several areas in Indonesia, among them: 1) a Breezy Eco Park village, which is located in the village of Ngempe, district Bawen, Semarang Regency, in Central Java; 2) The Blooms Garden, residing in Banjarbatusesa, village Candikuning, Baturiti District, 3) Ice cream
World and Sunflowers Garden Tabanan Regency, Bali, Kuta and Jimbaran beaches; 4) Panama Park 825 Bandung; and 5) Lanterns Park Tegallega, Bandung.

Thus, from the above explanations, we can resume the benefits of using the Instagram that of as a media for selling products and finding new customers, but also selling interesting locations/places to attract people coming to those places.

The word Instagramable is actually a combination of two words, namely Instagram and "able". Instagram is a social media application that is used to share photos and videos. Whereas, the word 'able' means can, willing to, and capable. Then the meaning of the word Instagramable is something that can or worthy to be shared to Instagram profile, either in the form of photo as well as video (Baimbach, 2019). Hence, when talking about Instagramable places means talking about a location that has a view of the beautiful decorations that make Instagram users interested in coming and taking pictures and videos which are later uploaded to their Instagram profile respectively.

One of the most Instagramable places which become the goal of the millennial generation is the island of Bali. Bali is one of the tourist destinations in Indonesia that is very popular. Bali is also awarded annually, of which in the year 2016, Bali received awards from Travel + Pleasure as Top 5 Best Honeymoon place and became the fifth place of the world's best honeymoon, after Santorini, Maldives, Bora-Bora and Hawai. Bali is also placed as the best tourism destination in Asia and was in the second place for the world's tourist destinations (Benmetan, 2016).

In the year 2017, Bali was awarded as The Best Destination in TripAdvisor Travellers Choice Award. TripAdvisor is one of the leading tourist sites that helps travellers plan and book trips to find comparative destinations tourist attractions, hotels, restaurants and airlines with facilities or offer the best price. Based on the reviews from TripAdvisor on Bali, there was improvement in some aspects, such as the accommodation as much as $25 \%$, the performance as much as $38 \%$ and restaurants as $38 \%$ (Setyanti, 2017). 
The focus of this research is about the growth of an Instagramable places in island of Bali. Of course, this Instagramable places can give satisfaction to the user. However, the authors would like to find out further if there is a relationship between the level of satisfaction on the growth of Instagramable place and the user's motivation in increasing income?

This research is expected to contribute in the areas of academic, especially in the field of human resources on the topic of consumers' satisfaction and motivation so that this study can be used as a reference for researchers who study the same field by giving the readers an idea of the development of digital business that leverages the growth of the Instagramable places.

This research aims to provide information as well as a general overview about the relationship of the growing Instagramable places in enhancing the income of the Instagram users who have business by utilizing Instagram Marketing Strategy.

\section{Theoretical Foundation}

\section{Consumer Satisfaction}

According to Kotler (1997), consumer satisfaction is a feeling of happy or upset of someone who comes from the comparison of the effect on performance (or outcome) of a product and their expectations. Rangkuti (2002) argues that consumer satisfaction is defined as a consumer response against the mismatch between the previous expectation and actual performance perceived after usage.

Basically, the meaning of consumers satisfaction above covers the difference between expectation and performance or perceived results. So it can be concluded that the satisfaction means an emotional response that is perceived by the consumer at the time of using a product or service; so, it can be said that consumers feel satisfaction when the performance of a product or service is suited to their expectation.

\section{Factors that affect the level of satisfaction}

According to Santoso (2005) based on the model of consumer satisfaction with the method of the ACSI (American Customer
Satisfaction Index) which was developed by the American Society for Quality, the University of Michigan, ForeSee Result and Cloos Fornell International, consumer satisfaction is influenced by three factors: (1) Perceived Quality: This part is measured through three major things, namely the total satisfaction of product, reliability, and how far the products meet the needs of consumers; (2) Customer Expectation: the component of consumer expectations related to the combined consumer experience when consuming products and the influence of media promotion (advertising, sales promotion, promo word of mouth etc.); (3) Perceived Value: this component is concerned with the opinion of consumers about the price of product compared to its quality.

This research uses the theory of factors of satisfaction according to Santoso (2005), namely, perceived quality, customer expectation, and perceived value. Because the third of these factors not only describes the response or the perception of the consumer against the perceived product performance after discharging (perceived quality and perceived value) but also to assess the performance of these products by comparing consumer expectation with a product or service at the time before using the product or service.

\section{Consumer Motivations}

According to Setiadi (2003), motivation comes from the Latin 'movere' which means the urge or move. Motivation is important because this is the cause, channel, and support human behavior. In addition, Saputra and Samuel (2013) say that motivation is the impulsion in a person who generates an action. This impulsion resulted from the desire of the person that appears due to the needs that have not been fulfilled. The push factor in one's self (intrinsic factor), is directed by the individuals themselves to achieve a goal or a specific activity. Technology and information each year continue to progress so they influence the individual motivation to meet their needs.

So, it can be concluded that motivation plays an important role in influencing individual behavior. Motivation arises because of the need felt by the individual. The 
perceived needs encourage a person to take action to meet those needs.

\section{Factors that affect the motivation of Consumers}

There are several factors that affect the motivation of consumers in purchasing or using goods or services, i.e. (Abdurachman, 2004): (1) Quality factor: product attributes that are considered in terms of its physical benefits; (2) Prices factor: the sacrifice of ril and material provided by the consumer for acquiring or owning the product; (3) Factors of Brand: attributes that provide benefits to non material, namely consumer satisfaction.

\section{Previous Research}

There are some writing about social media. Siswanto in the article entitled "Optimization of Social Media as a marketing strategy for medium-small business" (2013) mentions that his research on social media is able to play a role as an Integrated Marketing Communication (IMC). Social media is able to perform the function of an integrated mix of promotions, even until the occurrence of the transaction process so that the actors of the SMEC were able to optimize their social media activities in their business. Methods of data analysis used is quantitative analysis, i.e. the classical assumptions of the test, $t$ test and $\mathrm{F}$ test, as well as the coefficient determination and multiple linear regression analysis. The respondents in this study were the actors of the SMEC that are able to optimize social media.

The next research is conducted by Nugraha (2015) entitled "The phenomenon of the Meme in the Media (The Study on Virtual Ethnography Posting Meme on Social Media Instagram users)". Nugraha is interested in researching the phenomenon of memes in social media because Instagram has recently become the new media phenomenon that is favored by the Indonesian, in particular adolescents to mature persons, so that the characteristics of virtual social media often produce a booming phenomenon among social media users themselves. The research method conducted by Nugraha is quantitative, with the study of virtual ethnography. The respondents in this study is the Instagram users who did the activity of posting meme.
Further research was carried out by Innova in the article entitled "The Motive and satisfaction of Instagram users in the community of Instameet Indonesia" (2016). The purpose of this research is to know the motives and satisfaction of the community of Instameet Indonesia in using Instagram. Instameet Indonesia is an Instagram community who are interacting and meeting to do photo hunting among users. Through Instameet, the Instagram users can get to know each other and having real interaction, do sharing and mutual inspiring.

Innova research results reveal that Instagram is a social media used as a place to disseminate and share information, interact with the crowd, as well as get to know closer with fellow users. This research uses a quantitative approach and descriptive research. Data collection methods used in this research is an email survey using a questionnaire. The respondents in this study amounts to 100 people with the result that the higher a person's motives using Instagram, will be increasingly higher satisfaction that someone wants to get.

\section{Research Methods}

\section{Type of Research}

The type of research used in this study is an associative or relationship research. Associative research is a research that aims to find out the relationship between two or more variables (Sugiyono, 1999). The independent variable in this study is the level of satisfaction on the growth of Instagramable place, and the dependent variable is motivation of the (Instagram) users in increasing income. As mentioned above, Instagramable places mean good, interesting and beautiful places that make Instagram users interested in coming and taking pictures and videos which then uploaded to their Instagram profile. So, users who are happy and satisfied with the places, they will be motivated to upload the photos and videos. Instagram accounts who have many followers, will gain advertising, which is indirectly means income.

\section{Population and Sampling}

The population in this research is the social media Instagram users that number is not limited. To select them, the researchers 
deploy questionnaires via a google form with a purposive method. The criteria as followed: (1) Social media users; (2) Instagram users who have ever visited Bali; (3) Users who are running business through Instagram Marketing Strategy.

The questionnaires were distributed in April and October 2019 to the network of authors. It turns out that only 130 people who filled out and returned the questionnaire, so that all the responsive respondents were deemed as a population. The author finally decided to take the whole population as a sample (saturated sampling).

\section{Methods and Instruments of Data collection}

The research method used is quantitative. While the data collection tools using a questionnaire. The authors make a questionnaire in the form of a Google Form, and the questionnaire disseminated via Whatsapp and Line. The questionnaire was created using a Likert scale of measurement: strongly agree (SS), agree (S), undecided or neutral $(\mathrm{N})$, disagree (TS), strongly disagree (STS).

\section{Data Processing and Analysis}

Data processing technique in this study using the SPSS program (Statistical Package for Social Science) version 16.0. Here, the authors used the Pearson Product Moment Correlation analysis technique to find out the relationship between the satisfaction variable at the Instagramable place with the user motivation variable in increasing income. According to Uyanto (2009), the Pearson product moment correlation is used to measure the strength of the linear relationship between two variables (having an interval scale or ratio scale). To be able to give an interpretation of the strength of the relationship between the two variables is done by looking at the number of intervals coefficient of correlation calculated results using Lind, Marchal, dan Wathen's frame (2013).

\section{Results}

\section{Validity Test}

The items in the dimension of consumer satisfaction and motivation of consumers are all valid.

\section{Reliability Test}

After measuring the test with Cronbach Alpha, we found the following results: Satisfaction variable $(\mathrm{X})$ has the value of 0.899 , and Motivation variable (Y) has a value of 0.869 . Thus, both variables are reliable and can be used in this research.

\section{Characteristics of Respondents}

Age

The characteristics of the age of the respondents in this study: less than 20 years old ( $16.2 \%), 21-25$ years old $(80 \%)$, and more than 26 years old $(3.8 \%)$.

\section{Income/allowance}

About $28.5 \%$ of respondents have an income/allowance of less than Rp 1 million, $55.4 \%$ of respondents have an income/allowance between $\mathrm{Rp} 1$ million - Rp 2 million, $14.6 \%$ of respondents have an income/allowance between IDR 3 to 4 million, and the rest as many as $1.5 \%$ of respondents have an income/allowance more than Rp 4 million.

\section{Frequency in uploading photos/videos}

As much as $47.7 \%$ of respondents occasionally uploading photos or videos about anything, such as food into Instagram account, $26.2 \%$ of respondents often upload photos or videos into Instagram account, and the rest as much as $26.1 \%$ respondents rarely upload photos or videos into Instagram account.

The frequency of daily activities through an upload feature instagram story

About $49.2 \%$ of respondents occasionally upload their daily activities via Instagram feature story, $23.1 \%$ of respondents rarely upload their daily activities via Instagram feature story, and the rest as much as $27.7 \%$ of respondents often upload the activities of everyday life through Instagram feature story.

The frequency of uploaded photo/video at tourism destination

As much as $45.4 \%$ of respondents sometimes uploading the tourism destination they visit into Instagram account, $19.2 \%$ of respondents rarely upload tourism destination they visit into Instagram account, and rest as much as $35.4 \%$ of respondents often upload 
the tourism destination they visit into Instagram account.

\section{Associative Hypothesis Testing}

From the analysis of the data processing obtained from the calculation manually by using the formula of Pearson Product, it is known that the value of correlation $\left(\mathrm{r}_{\mathrm{xy}}\right)$ is 0.486. These data show the strength and direction of the correlation coefficient of Lind, Marchal and Wathen. It concludes that the relationship between consumer satisfaction and consumer motivation variables has a slight moderate positive correlation.

The Variable Contribution Test of satisfaction against the motivation variable

To search for a variable contribution of satisfaction towards motivation variables we use the following formula:

$\mathrm{KP}=\mathrm{r} 2 \times 100 \%$

$=(0,486) 2 \times 100 \%$

$=0,236196 \times 100 \%$

$=23,61 \%$

Meaning: the variable of satisfaction contributes to motivation variable as much as $23.61 \%$ and the rest is determined by other variables/factors.

\section{Test Signicance Of the Correlation Test using Product Moment}

If $t$ test $\geq t$ table, then Ho is rejected means it is significant; and if $\mathrm{t}$ test $\leq \mathrm{t}$ table, Ho is accepted, mean insignificant. Based on calculations by taking the value of $\alpha=0.05$ and $\mathrm{n}=130$, using test one party then: $\mathrm{dk}=\mathrm{n}$ $\mathrm{k}-1=130-1-1=128$, so that we have a result of $t$ table $=1.65685$. It turns out that the calculation of $t$ test (Product Moment Correlation Test) is more of the table or 6.32 $>1.65685$ then there is a significant relationship between the variable of satisfaction at the growth of Instagramable place and the variable of user motivation in increasing earnings/income.

\section{Discussions}

User Satisfaction with Instagramable Places
Customer satisfaction is the consumer's feeling which is the result of evaluation after comparing what he received with what was expected. Based on the calculation of the correlation test, consumer satisfaction results in a correlation value of 0.486 . That means, the quality of the overall characteristics of each component that makes up a product or service for an Instagramable place is in accordance with what users expect so that users are satisfied with the existence of an Instagramable place.

\section{User Motivation to Increase Income}

Consumer motivation is a process that encourages or influences someone to get or achieve what they want or what they need. Quality and brand influence purchasing decisions or consumer decisions in using products or services in order to achieve or fulfill their needs or desires. The consumer motivation variable based on the Pearson correlation calculation produces a correlation value of 0.486 . This means that perceptions of quality and brand generate a positive response. That is, users assess the quality and brand in the resulting photos which have an important role, namely being able to attract 130 other users to visit Instagram profiles, become followers, and give likes so that this will encourage purchase decisions or decisions in using photos by other Instagram users. The more users who expose photos of food or tourist destinations, it will also increase the appearance of Instagramable places. The emergence of these Instagramable places is used by a number of users to produce attractive and instagenic photos that can help users increase their income. The more photos/videos are uploaded by users, the more people will like them, and the more money users will obtain. So, a purchase decision or a decision to use the photos will motivate users to increase income.

\section{Conclusions and Suggestions}

\section{Conclusion}

Based on the results of the analysis described above, researchers conclude that there is a positive relationship with the level of strength is slightly moderate between the level of satisfaction on the growth of 
Instagramable place and the user motivation in increasing earnings/income.

\section{Suggestions}

For the next research, it is suggested that in addition to using quantitative methods, qualitative methods can also be used to get the in-depth information about the relationship on the growth of Instagramable place for the user to the increase earnings/income.

This research focuses on the relationship of Instagramable places against social media Instagram users, so for the next study, it could be focused on the impact of the use of social media Instagram against the community that uses the Instagramable place for their business opportunity.

For the users of social media Instagram who benefit from the growth of Instagramable place scattered in some areas especially in the island of Bali, in order to increase their income, they can also take advantage of some of the results of their photos to promote Bali as a tourism destination of Indonesia, so that more and more tourists will come to visit Indonesia especially, especially to Bali.

\section{References}

Kementerian Komunikasi dan Informatika Republik Indonesia. (2014, November 24). Diambil kembali dari kominfo.fo.id: https://kominfo.go.id/content/detail/4286 /pengguna-\%20internet-indonesianomor-enam-dunia/0/sorotan media

Abdurachman, U. (2004). Analisis FaktorFaktor yang Menimbulkan Kecenderungan Minat Beli Konsumen Sarung (Studi Perilaku Konsumen Sarung di Jawa Timur). Jurnal Manajemen \& Kewirausahaan, Vol. 6, No. 1, 34-53.

Baimbach. (2019, Februari 8). Kompasiana. Diambil kembali dari Kompasiana Web Sites:

https://www.kompasiana.com/baimbach2 019/5c5d39f3677ffb68c624aa35/apa-ituinstagramable-berikut-adalah-arti-danpenjelasannya

Benmetan, T. (2016, Oktober 11). Good News from Indonesia. Diambil kembali dari goodnewsfromindonesia.id: https://www.goodnewsfromindonesia.id/ 2016/10/11/lagi-lagi-pulau-bali-raihpenghargaan-pariwisata-dunia

Clement, J. (2018, June). Statista Company. Diambil kembali dari Statista Web Sites: https://www.statista.com/statistics/25357 7/number-of-monthly-active-instagramusers/

Innova, E. I. (2016). Motif dan Kepuasan Pengguna Instagram di Komunitas Instameet Indonesia. Jurnal eKomunikasi, Vol. 4, No. 2.

Kotler, P. (1997). Manajemen Pemasaran. Edisi Bahasa Indonesia. Jakarta: Prentice Hall.

Kurniawan, S. (2018, November 11). Marketeers.com . Diambil kembali dari Marketeers Web Sites: $\mathrm{http}: / /$ marketeers.com/instagram-makinpopuler-di-kalangan-umkm/

Nugraha, A. (2015). Fenomena Meme di Media Sosial (Studi Etnografi Virtual Posting Meme pada Pengguna Media Sosial Instagram). Jurnal Sosioteknologi, Vol. 14, No. 3.

Rangkuti, F. (2002). Measuring Consumer Satisfaction. Jakarta: PT. Gramedia Pustaka Utama.

Santoso, S. (2003). Mengatasi Berbagai Masalah Dengan SPSS VERSI 11.5. Jakarta: PT. Elex Media Komputindo.

Santoso, S. (2005). SPSS dan Excel untuk Mengukur Sikap dan Kepuasan Konsumen. Jakarta: PT. Elex Media Komputindo Kelompok Gramedia.

Saputra, R., \& Samuel, H. (2013). Analisa Pengaruh Motivasi, Persepsi, Sikap Konsumen terhadap Keputusan Pembelian Mobil Daihatsu Xenia di Sidoarjo. Jurnal Manajemen Pemasaran, Vol. 1, No. 1, 1-12.

Setiadi, N. J. (2003). Perilaku Konsumen: Perspektif kontemporer pada motif, tujuan, dan keinginan konsumen. Jakarta: Kencana Prenada Media Group.

Setyanti, C. A. (2017, Agustus 3). CNN Indonesia. Diambil kembali dari $\mathrm{CNN}$ Indonesia Web Sites: https://www.cnnindonesia.com/gayahidup/20170803071147-262- 
232085/restoran-di-bali-raihpenghargaan-terbaik-se-asia

Siswanto, T. (2013). Optimalisasi Sosial Media Sebagai Media Pemasaran Usaha Kecil Menengah. Jurnal Liquidity, Vol. 2, No. 1, 80-86.
Sugiyono. (1999). Metode Penelitian Bisnis. Bandung: IKAPI.

Sugiyono. (2007). Statistika Untuk Penelitian. Bandung: IKAPI.

Uyanto, S. S. (2009). Pedoman Analisis Data dengan SPSS. Yogyakarta: Graha Ilmu. 